University for Business and Technology in Kosovo

UBT Knowledge Center

UBT International Conference

2013 UBT International Conference

Nov 2nd, 11:30 AM - 11:45 AM

\title{
The Analysis of Interface of Social-Technical Aspects within Transport Planning and Urban Design
}

\author{
Ylber Limani \\ University for Business and Technology, ylber.limani@ubt-uni.net \\ Binak Beqaj \\ University for Business and Technology, bbeqaj@ubt-uni.net \\ Vlora Aliu \\ University for Business and Technology, vlora.aliu@ubt-uni.net
}

Follow this and additional works at: https://knowledgecenter.ubt-uni.net/conference

Part of the Architecture Commons

\section{Recommended Citation}

Limani, Ylber; Beqaj, Binak; and Aliu, Vlora, "The Analysis of Interface of Social-Technical Aspects within Transport Planning and Urban Design" (2013). UBT International Conference. 11.

https://knowledgecenter.ubt-uni.net/conference/2013/all-events/11

This Event is brought to you for free and open access by the Publication and Journals at UBT Knowledge Center. It has been accepted for inclusion in UBT International Conference by an authorized administrator of UBT Knowledge Center. For more information, please contact knowledge.center@ubt-uni.net. 


\title{
The Analysis of Interface of Social-Technical Aspects within Transport Planning and Urban Design
}

\author{
Ylber Limani 1, Binak Beqaj², Vlora Aliu $^{3}$ \\ 1,2,3 University for Business and Technology, \\ Department of Architecture and Spatial Planning, \\ Prishtina, Kosovo \\ ylber.limani@ubt-uni.net, bbeqaj@ubt-uni.net,vlora.aliu@ubt-uni.net
}

\begin{abstract}
This paper discusses the essentials of social-technical aspects of urban development and transport planning. It describes the role and position of human factor in urban development and transport planning and its interface with technical elements. The paper argues the possibilities of optimization of the correlation between human factors and technical elements using the social-technical insights related turban design and transport planning. The research methodology has been based on qualitative empirical and theoretical approaches using the methods of combination the direct observation and the analys is of documents, and the literature. The working methodology has been based on the concept of organizational science emphasizing the importance of balance between human health, well-being and technological effectiveness.
\end{abstract}

Key words: urban development, transport planning, sus tainability, social aspects, technical factor

\section{Introduction}

The social-technical aspects of urban development and transport areas are various, and the prospect of extracting and using them is abundant. Since the concept of sustainable development was placed on the agenda of many planners and developers, the social aspects together with economic and environmental aspects have been studied and included in the policies, plans and programs, and in the various projects around the world. However, the requirements of sustainable development conception concerning urban development and transport planning are complex and they need more research. Transport Planning (TP) and Urban Design (UD) developments should be considered together, specifically the social-technical aspects in this regard are important and they require higher attention. In this paper, we adopt that the concept of sustainable development would not be implemented without fully incorporation of social, environmental, and economic issues. Moreover, we recognize that this concept is changing because of changing the social/human needs in one side, and engineering opportunities at another side. Consequently, there are discussions among the urban and transport planning communities concerning the inclusion of other factors to the concept of sustainability such as sustainable urbanization (UN, 2008), and sustainable transport (Black, 2010; Limani and Beqaj, 2012). In this matter, social-technical aspects of UD and TP are highly important since they are considered to be an essential measure of the triple-bottom line for sustainable development.

This research is performed concerning a central question:

How might the transport planning and urban design may be more effectively understood in order to contribute in building of more sustainable social environment?

The sub-questions raised in this research try to answerhow the social-technicalaspects of transport and urban development interact with each other, and how they should be managed in certain dec ision making under uncertainties. The approach is supposed to serve as a module for educational objectives and as a tool for improving the awareness and decision-making behaviour of engaged governmental departments, individuals and other community groups in urban design and transport planning.

The research is further limited to the analys is of social-technical interface within the transport planning and urban design. This analysis is performed combining the qualitative and quantitative research 
methods. Subsequently, the resolution of this research is categorized as exploratory, descriptive and explanatory.

Explorative study addresses the questions concerned with the identification of the contemporary circumstances concerning social aspects of transport and urban development by assessing the related events in an original approach. In this regard the depth analys is of social-technical aspects of TP and UD is undertaken. The dataset generated fromthis analys is is used to further analyse the interface within TP and UD.

In the first part of Section 2 the social-technical aspects of transport planning is performed showing the main issues in this regard (Limani and Beqaj, 2012). The second part of Section 2 shows the analysis of social-technical as pects of urban design. This analys is has been performed by examining two distinct assessments. First exploration includes the ass essment of the social value of urban design, where social technical-aspects of UD are identified and analysed (Ministry for the Environment, 2005).

Descriptive study is concerned with the most possible description of related studies, events, engaged individuals and groups, users, technology and related environments.

With a short explanatory study, this paper founds and reports some remarkable and valuable relationships between human factors (social issues) and technical variables (land use and spatial elements) in the field of urban design and transport planning. The relationship between UD and TP is analysed through scenario development and s cenario analys is. In this respect, the results concerned with the relationship between UD and $\mathrm{TP}$ are presented. In the conclusions, particular significant recommendations are given, which are aimed for educational and decision-making purposes.

\section{The analysis of social-technical aspect within transport planning and urban design}

\subsection{Social-technical aspects within transport planning}

The simple understanding of transport purpose is to benefit the society. In this perspective there are some conditions constrained with transport when its impact on the society need to be assessed. The essence of the existence and the development of transport is to provide mobility for people and haulage for goods. However, this simple resolution has become more critical and complex when rising social needs have been converted into transport issues. Transport planning should create preconditions for a transport which will provide with mobility and accessibility for all, which is safe, secure and fair, which will minimize accidents and will increase equity, and which will be environmentally responsible. Moreover, transport should be able to maintain a degree of mobility to contribute effectively to the economic development of countries and regions. In the latitude of sustainable transport, transport planning objectives should be directed to maximise mobility and accessibility, to maximise community cohesion, to minimise traffic noise, to reduce and possibly to eliminate accidents, to reduce air pollution, and to protect valuable cultural objects and places.

Though, this part of research is focused on social-technical aspects of transport planning, the discussion will be further focused on envisioned topic. The impact of transport on the society is supposed to produce positive effects, however, often it produces negative effects (Limani and Beqaj, 2012).

Most important social as pects of transport planning that further have been analysed in this research are listed as follows: accessibility, mobility, equity, safety, security, noise, community cohesion, and preservation of cultural objects and areas (Limani and Beqaj, 2013).

\subsection{Equity}

Social equity reflects the protection of fundamental rights of all people and ensuring that, regardless of age, income or disability, all communities enjoy equal access to all aspects of society (employment, access to public services or educational institutions, enabling consumer and recreational possibilities). Equity means neutrality and objectivity guiding reflection to the suitable dissemination of benefits and costs of trans port.

The equity can be analysed depending on how, where and when the measurement of transport occurs . 
In general three types of equity should be included in transport planning (Litman, 2002):

- Horizontal equity, which treaties everybody equally. Transport user pays, while individuals bear the costs they impose without favouring one group to another.

- Vertical equity with regard to income and social level, which supports transport subsidies for disadvantaged groups and opposes the price increase.

- Vertical equity with regard to mobility need and ability, which as sumes that everyone should enjoy the basic level of access and mobility.

Horizontal equity is well measurable taking into consideration it is based on transport investment costs. This equity type is most common in transport analysis because it considers market effects. Vertical equity with regard to social level can be measured by taking into account the basic mobility needs of disadvantaged people and possibilities of balancing other types of travel (business, luxury and leisure).

Vertical equity considering mobility needs and ability should be analysed in terms of mobility needs (luxury or essential) and in terms of ability (non-drivers, low-income drivers, persons with disabilities). Equity is a difficult subject to be measured; however there are many ways of measuring it. The equity as an indicator of socialand economic impacts of transport should be disaggregated in smaller indicators to be measured (Limani and Beqaj, 2012). Affordable housing and activity accessibility, share of transport costs, quality of accessibility for people with disadvantages (TRB, 2008).

\subsection{Accessibility and mobility}

Accessibility and mobility are two pointers having most consideration in transport planning. Depending on the impact area the mobility and accessibility may reflect multiple impacts. They can measure both impacts of transport: social and economic. Accessibility may be more attributed to measure transport social impact, while mobility may be attributed to measure transport economic impact. However, there is a considerable degree of simultaneous impact of both mobility and accessibility in the social life of people.

Accessibility at the social level is defined as the ease of access for all people in different locations where they can travel to their activity place using desired and needed transport system modes and facilities (TRB, 2008). Decisions affecting accessibility can be complex. Even a well specified accessibility indicator such as the total average travel time to a specified workplace for residents of an area includes many complexities about walking, public transport schedules, road congestion, and the travel time being substituted, work on roads and urban areas, accidents, and people's ability to use a specific mode or to access a transport facility, etc.

Mobility and accessibility represent two main influences of transport on the society and at this level they can be measured against their quality. Indicators for quality measurement may be affordability, access to employment and social services, educational opportunities and household tasks, quality of accessibility facilities for people with disabilities, inclusion possibilities improvement through enhancing pedestrian, cyclist and public transport spaces and facilities (Limani and Beqaj, 2012).

\subsection{Safety and security}

Transport planning objectives should be based on more safe and secure traffic for all users. Despite of the many improvements in EU transport policy related to safety and security issues shows the number of people killed by accidents remains high. In 2009 in road accidents in the EU, 34826 persons were killed (EC, 2011), and in the USA from total transport accidents 35929 people were killed in 2008 (U.S. DOT, 2011). Although the number of road fatalities was lower by more than a third in comparison with 2001, road accident remains the main cause of fatalities and injuries, crashes, loss of properties and opportunities. The main measurable indicator which indicates safety and security item is the accident. Accident as an indicator at social level can be measured through negative effects produced and consequences such number of fatalities, injuries, losses from crashes (substantial measurable and psychological difficult to measure losses), and opportunity losses. The transport planning objectives should be oriented to increase road safety and to reduce crash risks. Comprehensive evaluation of transport systemcomponents could be more effective to increase safety and security than examining the 
whole transport system. Utilising this method transport system component may become positive feedback system by considers more integrated solutions and providing multiple benefits.

\subsection{Noise}

Transport noise has been qualified to have negative effects on the environment by disturbing the wildlife and on the human health. Increasing noise levels have a negative impact on the urban environment reflected in falling land values and loss of productive land uses. The World Health Organisation (WHO) has defined the noise annoyance as a feeling of displeasure induced by noise. However, noise above 50 decibels $(\mathrm{dB})$ is considered to be dangerous for human health. According to the WHO noise impact produces following effects: annoyance, speech intelligibility and communication interference, distribution of information extraction, sleep disturbance, and hearing impairments, (WHO, 1999). According to the United Nations Economic Commission for Europe and WHO, it has been estimated that about $30 \%$ of EU15 are exposed to levels of transport noise more than $55 \mathrm{~dB}$ (A), although WHO limits noise levels for residential areas to $55 \mathrm{~dB}$ during the day and $45 \mathrm{~dB}$ during the night (UNECEWHO, 2008). The UK has well established procedures for assessing the annoyance to people caused by road and rail traffic-related noise and vibration. UK Department for Transport has recently commissioned a research study aimed at converting noise impacts to monetary value.

\subsection{Community cohesion and preservation of cultural areas}

Community cohesion means the level of configurations of social networking within a region or community. Transport is vital in connecting people with their residences, workplaces, schools, hospitals and other activity locations. Efficient transport planning should consider all possibilities in order to find better solutions for balanced accessibility and efficient mobility of all categories of people. Contrary, poor transport planning and insufficient facilities possibly will lead to social exclusion, inequity, destruction of cultural heritages, more accidents, and noise above allowed levels, and the disturbance of communities.

Table 1: The summary of social as pects of transport planning

\begin{tabular}{|c|c|c|}
\hline $\begin{array}{l}\text { Social } \\
\text { Technical } \\
\text { aspects of } \\
\text { Sustainable } \\
\text { Transport } \\
\text { Planning }\end{array}$ & $\mathbf{R}$ & Social Values and/or disvalues \\
\hline Accessibility & 29 & $\begin{array}{l}\text { Accessibility at the social level is defined as the ease of access for all } \\
\text { people in different locations. } \\
\text { Primarily concerns people with special needs such as people with reduced } \\
\text { mobility, disabled people, elderly people, and families with young } \\
\text { children and the young children themselves (EC 2010). }\end{array}$ \\
\hline Mobility & 20 & $\begin{array}{l}\text { Safe and secure movement of people. } \\
\text { Mobility and accessibility have a considerable degree of simultaneous } \\
\text { impact on the social life of people. }\end{array}$ \\
\hline Equity & 17 & $\begin{array}{l}\text { Ensures that the benefits and costs of transport are reasonably equally } \\
\text { distributed. } \\
\text { Focuses particularly on users with special needs. } \\
\text { Concerns with improving accessibility, saving the environment and } \\
\text { providing safety (EC 2010). } \\
\text { Protects user's interests and rights. }\end{array}$ \\
\hline $\begin{array}{l}\text { Safety and } \\
\text { security }\end{array}$ & 15 & Safe and secure traffic for all users \\
\hline Noise & 13 & $\begin{array}{l}\text { Causes negative impact on the urban environment and on the social life } \\
\text { of people. It affects the health of people. }\end{array}$ \\
\hline $\begin{array}{l}\text { Community } \\
\text { Cohesion }\end{array}$ & 4 & $\begin{array}{l}\text { The level of configurations of social networking within a region or } \\
\text { community. }\end{array}$ \\
\hline
\end{tabular}




\begin{tabular}{l}
\hline $\begin{array}{l}\text { Pollution of } 2 \text { Has negative impacts on people's health and welfare. } \\
\text { air, soil and } \\
\text { water }\end{array}$ \\
Source: Limani \& Beqaj 2013
\end{tabular}

The impacts of transport on community cohesion may produce positive effects as well as negative effects. Positive effects possibly will generate new development, community and residential reliability and stability, may change property values, etc. Negative effects may indicate in inconsistency and isolation of residents from community facilities. This impact category is not relatively quantitatively measurable and it overlaps with a number of other impact categories (e.g., safety, noise, or urban sprawl).

\subsection{Pollution of air, soil and water}

The transport's other negative impact that produces negative effects for the social life of humans and for other living beings on earth is pollution of air, land and soil. This aspect is more related to the environmental impact of transport, therefore it will not be explored in this paper.

\subsection{The assessment of social value of transport planning}

The selected and previously described social-technical subjects in TP are further evaluated using common Multi-Criteria Analysis (MCA). The ranking of the subjects is performed by pairwise comparing the presented subjects with reference to the social aspect of TP. The results are displayed in

\subsection{The Analysis of Social-Technical aspects within urban design}

Urban design primarily reflects the necessity for social cohesion. It includes and requires individual and collective adaptability and resilience, acceptation, cooperation, organization and integration of various factors. It takes time and place simultaneously on a logical and planed scale. All these aspects of urban development have social, environmental and economic impact and they represent the factors for sustainable urbanization. Adaptability in urban development reflects the balance of urban system with the natural system and requires high tangible and intangible flexibility. Resilience or elasticity is represented from people, businesses, wealth, power and knowledge with a definite boundaries capable to develop and maintain a balanced state.

However, the urban development is recently based on practical issues such as landscape, energy efficiency, air quality, safety and security, water management, mobility, accessibility, time, space, costs and benefits, community cohesion, technology, etc. This research limits to the social-technical aspects of urban design, respectively social-spatial aspects of urban design.

The main social-technical aspects of urban development adopted in this paper are aspects expressed through pragmatism, cooperation, consciousness, confidence and integration. The social side of Urbanism may be simply explained through the interaction between societies and Urbanism, while the technical part may be explained by defining the interaction between engineering and Urbanism. The two assumptions are supported by the exploratory research of different approaches considering integration of social and spatial aspects of urban design.

\subsection{Integration of social-technical (spatial) aspects of urban: design-layered approaches}

Table 2: Social-technical aspects of urban design

\begin{tabular}{|c|c|}
\hline Key urban & Social Values \\
\hline $\begin{array}{l}\text { Local } \\
\text { character }\end{array}$ & $\begin{array}{l}\text { Reinforce a sense of identity among the residents of the neighborhood. } \\
\text { Encourages people to become actively involved in managing neighborhood. } \\
\text { Offers a choice among a wide range of distinct places and experiences }\end{array}$ \\
\hline Connectivity & $\begin{array}{l}\text { Enhances natural surveillance and security. Encourages walking and cycling, } \\
\text { mainly for non-work trips, leading to health benefits. Shortening walking }\end{array}$ \\
\hline
\end{tabular}




\begin{tabular}{|c|c|c|c|}
\hline & \multicolumn{3}{|c|}{ distances, encouraging people to walk. } \\
\hline Density & \multicolumn{3}{|c|}{$\begin{array}{l}\text { Is difficult to disentangle from the benefits of mixed use and other factors. Ca } \\
\text { contribute to social cohesion. Tends to promote health through encouragin } \\
\text { greater physical activity. Enhances vitality }\end{array}$} \\
\hline Mixed use & \multicolumn{3}{|c|}{ Improves access to essential facilities and activities } \\
\hline & \multicolumn{3}{|c|}{$\begin{array}{l}\text { Provides convenience. Encourages walking and cycling, leading to heal } \\
\text { benefits. Reduces need to own a car. Increases personal safety. Can enhan } \\
\text { social equity }\end{array}$} \\
\hline Adaptability & \multicolumn{3}{|c|}{ Increase diversity and duration of use of public space } \\
\hline & \multicolumn{3}{|c|}{ Gives ability to resist functional obsolescence } \\
\hline High quality of & \\
\hline public realm & \multicolumn{3}{|c|}{ Increased use of public space. } \\
\hline & \multicolumn{3}{|c|}{ Gives a greater sense of personal safety } \\
\hline & \multicolumn{3}{|c|}{ Attracts social engagement, pride and cc } \\
\hline & \multirow{2}{*}{\multicolumn{3}{|c|}{$\begin{array}{l}\text { Public art contributes to greater community engagement with public space } \\
\text { Encourages people to take advantage of opportunities presented by good urba }\end{array}$}} \\
\hline Integrated & & & \\
\hline Decision- & \multirow{2}{*}{\multicolumn{3}{|c|}{$\begin{array}{l}\text { design. Provides equity of opportunity for a range people to benefit fromgoo } \\
\text { urban design }\end{array}$}} \\
\hline making & & & \\
\hline User & \multicolumn{3}{|c|}{ Improves fit between design and user needs. } \\
\hline participation & \multirow{2}{*}{\multicolumn{3}{|c|}{$\begin{array}{l}\text { Develops user ownership of positive change. Enhances sense of community } \\
\text { sense of well-being and democracy. Legitimizes user interests. }\end{array}$}} \\
\hline & & & \\
\hline \multirow{2}{*}{\multicolumn{4}{|c|}{$\begin{array}{l}\text { Source: Adapted from the Ministry for Environment } 2005 \\
\text { Analysing the Table } 4 \text { the following subjects have been identified: identity, management, choice, saf } \\
\text { and security, health, socialcohesion, access, participation, convenience, equity, diversity, public spa } \\
\text { culture, social engagement, user needs, ownership, community, well-being, user ownership, u } \\
\text { interests, democracy. We suggest the inclusion of aesthetics and tradition as important subjects relat } \\
\text { to the local character of urban design. }\end{array}$}} \\
\hline & & & \\
\hline \multicolumn{4}{|c|}{ Cable 3: Relative importance of UD elements and extracted social-technical issues of UD } \\
\hline \multicolumn{2}{|l|}{ Key UD elements } & $\begin{array}{l}\text { Relative } \\
\text { Importance } \\
\text { for UD }\end{array}$ & Extracted social-technical issues of UD \\
\hline \multicolumn{2}{|l|}{ Connectivity } & $19 \%$ & Safety security, Health \\
\hline \multicolumn{2}{|l|}{ Density } & $5 \%$ & Mixed use, Social cohesion, Health \\
\hline \multicolumn{2}{|l|}{ Mixed use } & $12 \%$ & $\begin{array}{l}\text { Accessibility, Convenience } \\
\text { Health, Safety, Equity }\end{array}$ \\
\hline \multicolumn{2}{|l|}{ Adaptability } & $5 \%$ & Public space \\
\hline \multicolumn{2}{|c|}{$\begin{array}{l}\text { High quality of public } \\
\text { realm }\end{array}$} & $27 \%$ & $\begin{array}{l}\text { Cultural activities, Public space, Safety } \\
\text { Social engagement, Community engagement }\end{array}$ \\
\hline $\begin{array}{l}\text { Integrated } \\
\text { making }\end{array}$ & decision & $14 \%$ & Equity, Opportunity \\
\hline \multicolumn{2}{|c|}{ User participation } & $5 \%$ & User needs, User ownership \\
\hline \multicolumn{2}{|l|}{ Local Character } & $12 \%$ & Identity, Neighborhood management, Choice \\
\hline
\end{tabular}

Table 4:Ranking of shared and exceptional social-technical subjects of UD

\begin{tabular}{|c|c|c|c|c|c|}
\hline $\begin{array}{c}\text { Shared subjects } \\
\text { Safety and security (Health) }\end{array}$ & king & Ran & $\begin{array}{l}\text { Exceptional } \\
\text { subjects } \\
\text { Management }\end{array}$ & king & Ran \\
\hline
\end{tabular}




\begin{tabular}{llll}
\hline $\begin{array}{l}\text { Social cohesion (Social } \\
\text { engagement) }\end{array}$ & $16 \%$ & Public space & $4 \%$ \\
Accessibility (Convenience) & $13 \%$ & Choice & $4 \%$ \\
$\begin{array}{l}\text { Equity (Democracy, Well- being) } \\
\text { Culture }\end{array}$ & $11 \%$ & Diversity & $2 \%$ \\
$\begin{array}{l}\text { (Tradition/identity/aesthetics) } \\
\text { User needs (User interests) }\end{array}$ & $8 \%$ & & \\
$\begin{array}{l}\text { Public Participation (Community } \\
\text { engagement) }\end{array}$ & $7 \%$ & & \\
Ownership (User ownership) & $2 \%$ & & \\
\hline
\end{tabular}

The identified subjects are further approximately categorised into very important, important and less important as displayed in the Table 5. Analysing the subject displayed in the Table 5 we have concluded that there may be subjects that are coinciding among more than one urban design element. For this purpose, we have used simple multi-criteria analys is in order to clas sify the selected urban design issues. The table displays the results from the multi-criteria analysis.

\section{The interactivity (interface) within the transport planning and urban design concerning social-technical aspects}

From the view of the system thinking the urban system and the transport system are both social systems and physical-technical systems at the same time. The two systems consist of many dependent subsystems or sectors and they are difficult to be assessed. The dynamics of transport system depend on the dynamics of urban system and vice versa. Among many aspects of both systems, like economic, environmental, etc. The social-technical aspects of two systems highly depend on each other.

Transport planning and urban design should be considered as an interactive development representing the most important issued of urban dynamics. There are various aspects showing the necessity of treating urban design and transport planning interactively.

This paper is limited and focused on the social - technical interface within urban design and transport planning with the objective to provide more understanding of human demand related to transport and urban development. This section exploits and deduces the quantitative and qualitative studies carried out in the Section 2 and provides with the new perspective concerning the social-technical issues of transport planning and urban design. In this section the similar and different aspects of urban design and transport planning have been examined using multi-criteria analysis.

Through the synthesis of analysed is sues, only the similar aspects ofTP and UD hare further evaluated. This method is not dedicated to finding optimal solutions for potentially identified contexts. It is an approach with the purpose to support decision-makers and planners to analyse different issues of TP and UD, and to compare them in order to find their propervalues with respects to social aspect and their interaction altitude. It is more a pair comparis on method which compares each selected subject from the section 2 and evaluates those criteria alongside two main topics: TP and UD.

The results show the interaction altitude within TP and UD and validate our assumptions made in this research. 


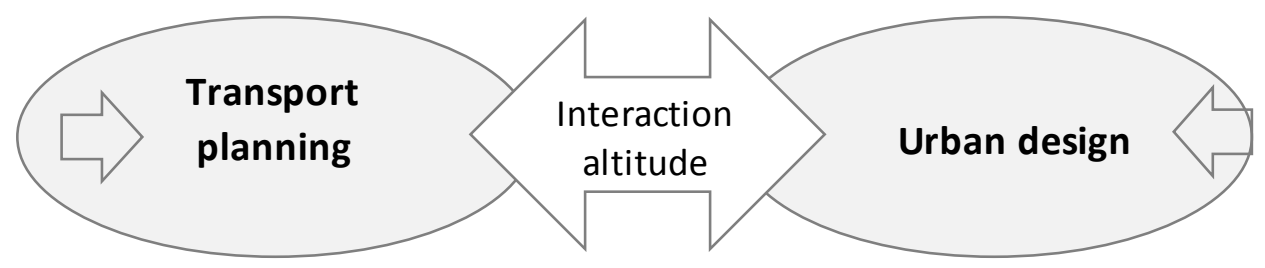

Fig 2: Transport planning and urban design- Interactive development

Table 5: Selected social issues for TP and UD

\begin{tabular}{|c|c|c|c|c|}
\hline \multirow[t]{2}{*}{$\begin{array}{l}\text { Social- } \\
\text { technical is sues }\end{array}$} & \multicolumn{2}{|c|}{$\begin{array}{l}\text { The Importance of } \\
\text { subjects in } \%\end{array}$} & \multicolumn{2}{|c|}{$\begin{array}{l}\text { The average } \\
\text { and } \mathrm{UB}(\text { in } \%)\end{array}$} \\
\hline & $\mathbf{T P}$ & UD & $\begin{array}{l}\text { Inc. } \\
\text { Other } \\
\text { iss ues }\end{array}$ & $\begin{array}{l}\text { Excl. } \\
\text { Other } \\
\text { issues }\end{array}$ \\
\hline $\begin{array}{l}\text { Safety and } \\
\text { security }\end{array}$ & 29 & 22 & 25 & 34 \\
\hline Accessibility & 20 & 13 & 17 & 23 \\
\hline Equity & 15 & 10 & 13 & 17 \\
\hline $\begin{array}{l}\text { Community/So } \\
\text { cial cohesion }\end{array}$ & 13 & 15 & 14 & 19 \\
\hline $\begin{array}{l}\text { Cultural Areas } \\
\text { Preservation/C } \\
\text { ulture }\end{array}$ & 2 & 8 & 5 & 7 \\
\hline $\begin{array}{l}\text { Other social } \\
\text { issues }\end{array}$ & 21 & 32 & 27 & \\
\hline
\end{tabular}

Table 5 displays selected social-technical subjects of TP and UD, which are used for further comparison and analysis. The selected subjects are approximately similar for both developments, therefore they are adopted as shared subjects within TP and UD.

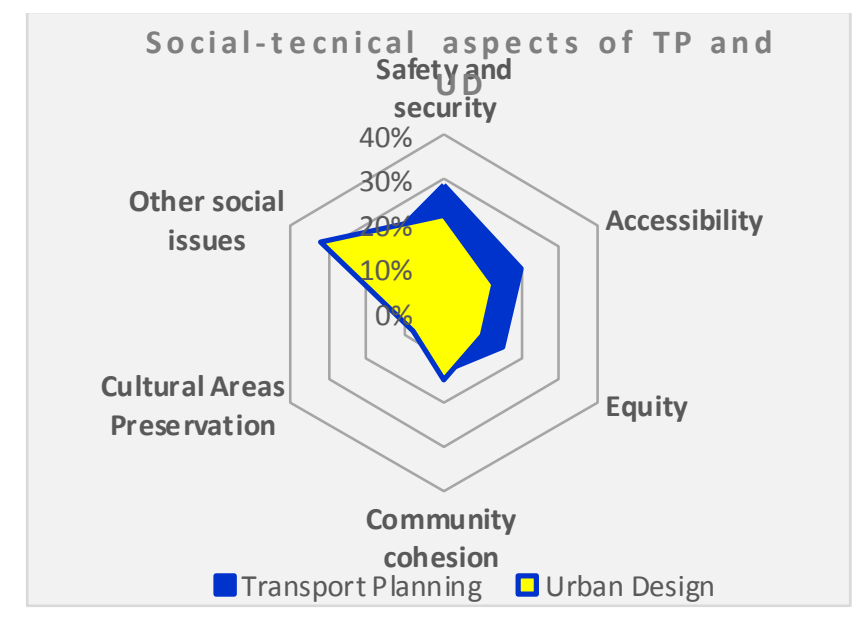

Fig 3: The comparison of main social-technical issues of TP and UD 


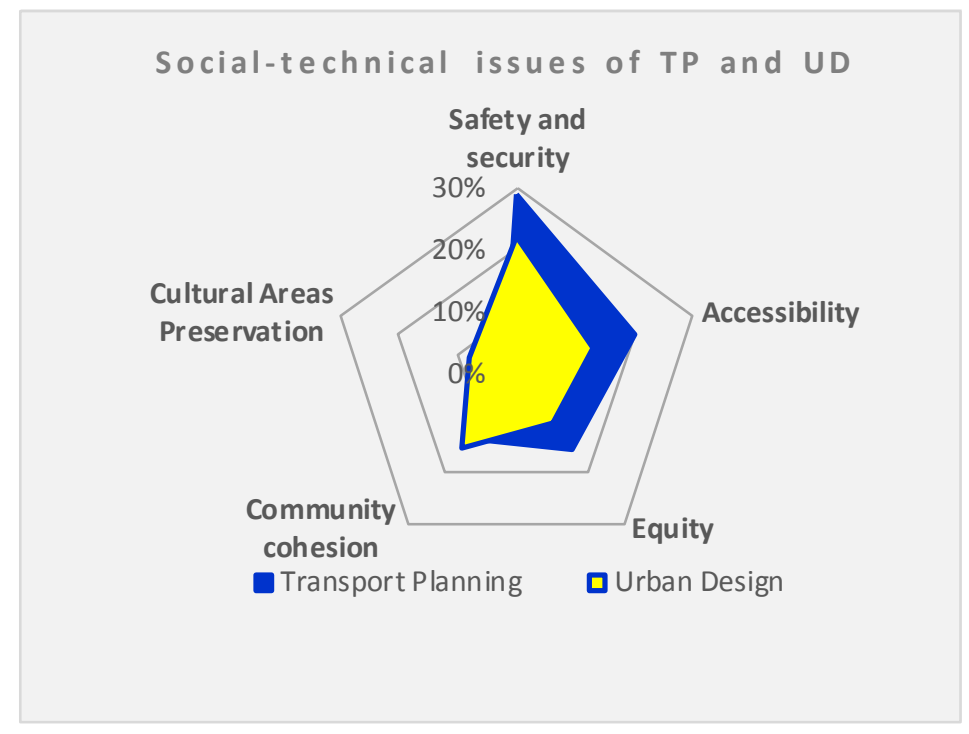

Fig 4: The comparis on of main social-technical issues of TP and UD (excluding other social issues)

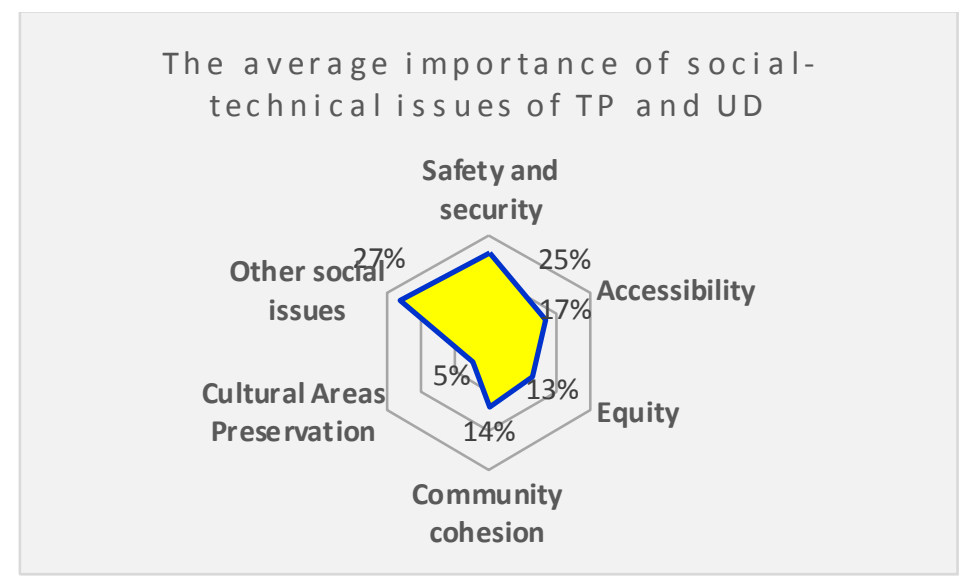

Fig 5: The average of main social-technical is sues of UD and TP

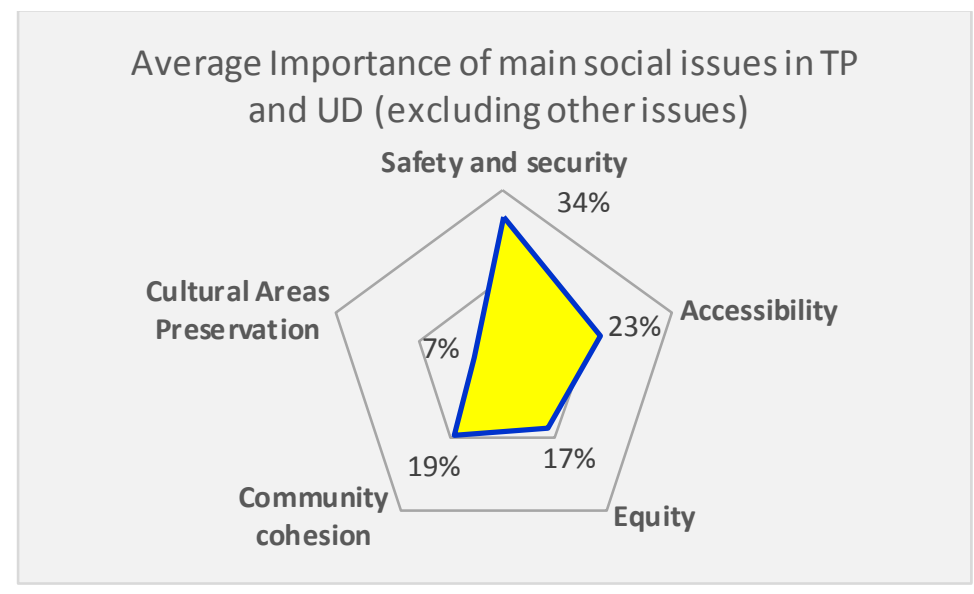

Fig 6: The average of main social-technical is sues of UD and TP (excluding other social issues) 


\subsection{Scenario development}

For the scenario development we used the dataset created in the previous sections. The dataset corresponds to the problem of identification and prioritization of UD and TP main elements. For the simplification of the research we have adopted four main elements (alternatives): high quality of public realm, connectivity, integrated decision making and mixed use. The selected alternatives are further evaluated against 5 criteria: safety and security, accessibility, equity, community cohesion, culture/preservation of cultural areas. For this purpose we have used VISUAL PROMITHEE 2 multicriteria method. The five selected criteria also have been used to evaluate four different alternatives, which are HQPR, Connectivity, Integrated DM and Mixed Use. For the simplification of research the adoption of these alternatives is made also for the transport planning topic.

\subsection{Scenario Comparison}

The scenario comparison is performed using Visual PROMETHEE method. The evidence is that UD scenario have more compact preference flow showing that HQPR is preferred to other alternatives. Integrated DM alternative is the worst case in both scenarios. In TP scenario HQPR shows better preference flow comparing with UP scenario. Connectivity and Mixed Use are approximately the same for both scenarios and show some kind of neutrality. However, connectivity shows better preference flow in both scenarios compared with Mixed Use. The conclusion is UD is more optimal when compared with UD relating to social-technical aspects, and the TP need more attention and requires more improvement.

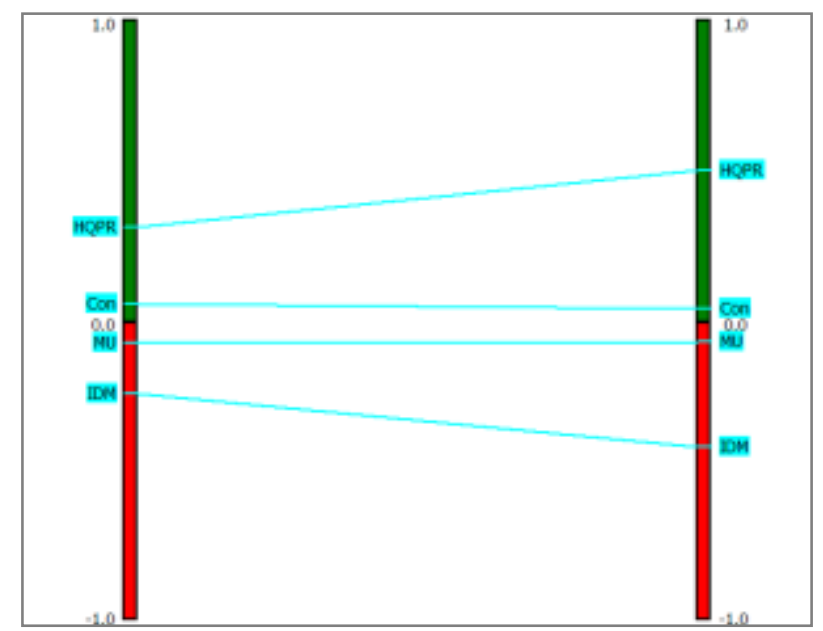

Fig 7: The results from scenario comparison

\subsection{Sensitivity analysis}

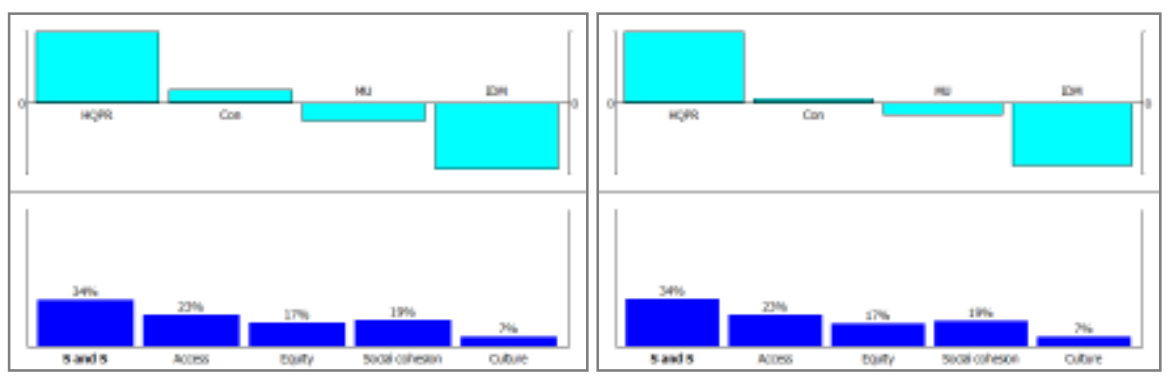

a)

b)

Fig 8: The demonstration of walking weighs a) UD scenario, b) TP scenario 


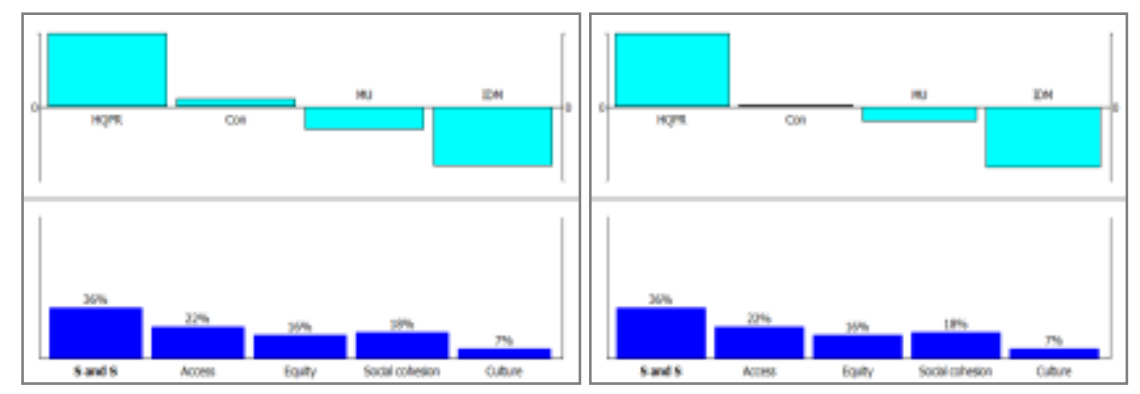

a)

b)

Fig 9: The demonstration of walking weighs after $5 \%$ increase of $S$ and $S$ criterion weight a) UD scenario, b) TP scenario

Table 6: Preference flows of alternatives in the TP Scenario

\begin{tabular}{|c|c|c|c|c|c|c|c|c|}
\hline \multicolumn{3}{|c|}{ TP } & \multicolumn{3}{|c|}{$\begin{array}{l}\text { Original } \\
\text { approach }\end{array}$} & \multicolumn{3}{|c|}{$\begin{array}{l}5 \% \text { Increase of Safety and Security } \\
\text { criterion }\end{array}$} \\
\hline \multirow[t]{5}{*}{ Rank } & & $\begin{array}{l}\text { Alternati } \\
\text { ve }\end{array}$ & Phi & Phi+ & Phi- & Phi & Phi+ & Phi- \\
\hline & 1 & HQPR & 0.2967 & 0.45 & 0.1533 & 0.5035 & 0.6138 & 0.1103 \\
\hline & 2 & $\mathrm{C}$ & 0.0567 & 0.33 & 0.2733 & 0.0148 & 0.3213 & 0.3065 \\
\hline & 3 & MU & -0.0767 & $\begin{array}{l}0.263 \\
3\end{array}$ & 0.34 & -0.0955 & 0.2921 & 0.3876 \\
\hline & 4 & IDM & -0.2767 & $\begin{array}{l}0.226 \\
7\end{array}$ & 0.5033 & -0.4228 & 0.261 & 0.6838 \\
\hline
\end{tabular}

The Figure 8 and Figure 9 display the effect of criteria weights and impact on the evaluated alternatives, respectively the sensitivity analys is using "walking weighs method". It represents the complete ranking of alternatives in the upper bar and the criteria weighing as conducted in the previous section in the lower bar. It can be identified that the HQPR alternative score is higher, while Integrated DM score is low. Between those two alternatives lies Connectivity with marginal positive score, and Mixed Use with the marginal negative score. This figure represents an original approach as established in the section 2 of this research work.

To conduct the sensitivity of our findings, the marginal decrease of input values, i.e., the weight of the criteria is performed as shown in the Figure 9. The increase of the weight of Safety and Security criterion of 5\% affects the other criteria as shown in the Figure 8a causes changes in the input value (weight) of Equity criterion. Consequently Equity criterion weight decreases for about $11.5 \%$. Regarding the results it may be concluded there is no much space to change some of criterion weight, no matter if they are considered to be positive. However in the complete ranked alternatives change is acceptable only for the alternative HQPR, since its preference flow increases as shown in the Table 7. Other alternatives have negative preference flow. The preference flows are computed to consolidate the results of pairwise comparis ons of the alternatives and to rank all the alternatives from the best to the worst ones. Positive flow measures how much one alternative is preferred to other alternatives. Negative preference flow measures how much other alternatives are preferred to one alternative. The net preference flow is the balance between the positive and negative flow. It can be both positive and negative. The larger the value of the net flow, the better the alternative.

Table 7: Preference flows of alternatives in the UD Scenario

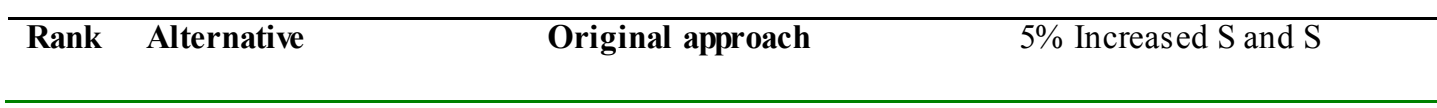




\begin{tabular}{lllllllll}
\hline & & Phi & Phi+ & Phi- & & Phi & Phi+ & Phi- \\
$\mathbf{1}$ & HQPR & 0.2975 & 0.4505 & 0.153 & 0.3065 & $\mathbf{0 . 4 5 5 7}$ & $\mathbf{0 . 1 4 9 3}$ \\
$\mathbf{4}$ & Connectivity & 0,0550 & 0.3292 & 0.2742 & 0.0375 & 0.3213 & 0.2837 \\
$\mathbf{3}$ & Mixed Use & -0.078 & 0.2627 & 0.3408 & -0.0923 & 0.2564 & 0.3487 \\
$\mathbf{2}$ & Integrated DM & -0.2745 & 0.2277 & 0.5022 & -0.2517 & 0.2383 & 0.4900 \\
\hline
\end{tabular}

As shown in the Figure 8 and in the Table 9 in the case of UD scenario the influence of increase input values is lesser than in the TP scenario. It may be resulted from the generalizations made in the case of alternative selection.

The conclusion is both UD and TP show improved preference flow when Safety and Security criterion increases in its importance. However, this finding will not tell us much about the interface within TP and UD concerning social-technical aspects since all studied aspects in this paper need to be maximized. It would be required to include other is sues that are supposed to be minimized, thus negative issues of TP and UD. This paper is limited to the analysis of interactivity within UD and TP concerning socialtechnical aspects, and for the simplification of research it includes main subjects with same altitude, i.e., with positive importance for both UD and TP.

The results show TP scenario to be weaker, while UD scenario stronger when they become concerned with the social-technical aspects. This would mean TP needs more research and more improvement in order to become more sustainable. There is also space for improvement of UD considering that socialtechnical is sues need to be more accurately balanced and prioritized.

\section{Conclusions and recommendations}

This research has been focused on the interactivity issue of TP and UD concerning social-technical aspects. This means that we have analysed many underlying issues, and finally we have selected some of important subjects to analyse and to compare them. The results show how the social-technical aspects of UD and TP should be assessed and prioritized in the decision making process under certainty. A conclusion can be drowned that the transport and urban developments impact on society produces positive and negative effects and the designing and planning objectives should be directed in mitigating negative effects of transport and urban development and in promoting and continuously improving positive effects of UD and TP on the society. Another important conclusion is that in the case of TP, it would not be a good solution when planners get highly focused on one is sue, no matter how such is sue may be important. In this research we have concluded that even when the sensitive issue such Safety and Security criterion become increased in its value or weight, it will not produce positive effects for all alternatives. In conclusion three main indicators of community cohesion adopted in this research are: quality and quantity of community interaction; property value change, and community activity participation level. The subjects identified as an important for urban design should be captured by the urban development responsible and engaged authorities. The urban authorities can correct any eventual deficiency by developers using the criteria developed in this paper. Urban design elements may be included in the creation of urban design protocol there where it does not exist. Concerning other important issues, which have not been captured by this research, it may be recommended more research in the frame of sustainable development, especially in the frame of economic and env ironmental aspects of UD and TP. It would be also recommended to conduct more research in the direction of the policy and planning level in order to enforce the regulations concerned with the social-technical issues of TP and UD. The legal regulations should be based on prevention and reduction of improper behavior of policy makers and planners in the field of TP and UD. The research should be conducted to explore the negative effects of TP and UD as sub-systems and as a whole system. This may include urban sprawl, 
car dependency, noise pollution, air pollution, congestion, land use, land take, land fragmentation, energy use, aesthetics and biodiversity, etc.

\section{References}

1. Black, W. R. (2010). Sustainable Transportation: Problems and Solutions. The Guilford Press, New York, London.

2. EC (2010). Thematic Report Summary: Equity and Accessibility. Transport Research Knowledge Centre [online]. Available at: http://www.transport-research.info/web/index.cfm.

3. EC (2011a). EU Energy Transport in Figures. Statistical Pocketbook 2011. Office for Official Publications of the European Communities, Luxemburg.

4. Limani Y., Beqaj B. (2012). An Approach for Integration of Sustainable Transport Planning Indicators. International Conference on Business, Technology and Innovation, Prishtina, Kosovo. ISSN66488.

5. Limani Y., Beqaj B. (2013). Improving Transport Planning Policy in Developing Countries of Western Balkan Region Using Inclusive Integration Methodology: Exploration and Comparative Development.

6. Litman T. (2002). Evaluating Transportation Equity. World Transport Policy \& Practice, Volume 8 , Number 2, (2002) 50-65.

7. Ministry of the Environment (2005). The Value of Urban Design. The Economic, Environmental and Social benefits of Urban Design [online]. Ministry for the Environment, Wellington.

8. TRB (2008). Sustainable Transportation Indicators Subcommittee of the Transportation Research Board (ADD40 [1]). Paper 09-3403, 2009 Transportation Research Board Annual Meeting [online]. Available at: http://www.vtpi.org/sustain/sti.pdf.

9. U.S. DOT (2011). Research and Innovative Technology Administration Bureau of Transportation Statistics. National Transportation Statistics 2011, Washington.

10. UN (2008). Achieving Sustainable Development and Promoting Development Cooperation. Dialogues at the Economic and Social Council. United Nations Publications, New York.

11. UNECE-WHO (2008). Transport, Health and Environment: Trends and Developments in the UNECE-WHO European Region (1997-2007). New York.

12. WHO (1999). Guidelines for Community Noise. World Health Organisation, Geneva. 